\title{
PERANCANGAN BOOST CONVERTER SEBAGAI SUPLAI INVERTER MENGGUNAKAN DSPIC30F4011 DENGAN METODE KONTROL PROPORTIONAL INTEGRAL
}

\author{
Irkham*), Iwan Setiawan, and Agung Nugroho \\ Departemen Teknik Elektro, Universitas Diponegoro \\ Jl. Prof. Sudharto, SH, Kampus UNDIP Tembalang, Semarang 50275, Indonesia \\ ${ }^{*}$ E-mail: irkham254@gmail.com
}

\begin{abstract}
Abstrak
Energi fosil adalah energi yang paling banyak digunakan, namun ketersediaan bahan bakar fosil semakin menipis. Energi terbarukan dapat digunakan sebagai salah satu alternatif pemenuhan energi. Panel surya adalah salah satu energi terbarukan yang bekerja dengan mengubah energi matahari menjadi energi listrik. Pemanfaatan panel surya sebagai pembangkit dapat dihubungkan lagsung dengan grid melalui sebuah inverter. Permasalahan ketika panel surya dihubungkan ke grid adalah tegangan panel surya lebih rendah dibanding nilai tegangan grid. Digunakan boost converter untuk menaikkan tegangan DC. Tegangan keluaran panel surya tergantung pada iradiasi dan beban yang disuplai panel surya. Untuk menjamin tegangan keluaran panel surya konstan, diperlukan umpan balik tegangan pada konverter DC-DC. Pada Penelitian ini dirancang boost converter mengunakan umpan balik tegangan dengan sistem kontrol proportional integral. Tahapan perancangan diawali menghitung komponen boost converter, verifikasi menggunakan software PSIM dan implementasi perangkat keras. Boost converter telah berhasil dibuat, dari pengujian menggunakan umpan balik tegangan variasi tegangan masukan dengan nilai keluaran dijaga konstan pada nilai 50 volt pada parameter kontrol $\mathrm{Kp}=0.5$ dan $\mathrm{Ki}=0.0$, tegangan keluaran pada keadaan steady state memiliki nilai error rata-rata sebesar $30 \%$ dari set point, pada parameter kontrol $\mathrm{Kp}=0.0$ dan $\mathrm{Ki}=0.1$ tegangan keluaran pada keadaan steady state memiliki nilai error rata-rata sebesar $0 \%$ dari set point, pada parameter kontrol $\mathrm{Kp}=0.5$ dan $\mathrm{Ki}=0.1$ tegangan keluaran pada keadaan steady state memiliki nilai error rata-rata sebesar $0 \%$ dari set point.
\end{abstract}

Kata kunci: panel surya, boost converter, proportional integral

\begin{abstract}
Fossil energy is the most widely used energy, but the availability of fossil fuels is running low. Renewable energy can be used as an alternative energy fulfillment. Solar panels are one of the renewable energies that work by converting solar energy into electrical energy. Utilization of solar panels as generators can be connected directly with the grid via an inverter. The problem when the solar panel is connecting to the grid is the voltage of the solar panel lower than the grid voltage value. Used boost converter to raise DC voltage. The output voltage of the solar panel depends on the irradiation and the load supplied by the solar panel. To ensure constant solar panel output voltage, voltage feedback is requiring in DC-DC converters. In this Research designed boost converter using voltage feedback with proportional integral control system. The design stage begins to calculate the component boost converter, verification using PSIM software and hardware implementation. Boost converter has been made, from the test using voltage feedback variation of the input voltage with the output value is kept constant at the value of 50 volts on the control parameter Kp $=0.5$ and $\mathrm{Ki}=0.0$, the output voltage in the steady state has an average error value the average of $30 \%$ of the set point, the control parameter $\mathrm{Kp}=0.0$ and $\mathrm{Ki}=0.1$ the output voltage in the steady state has an average error value of $0 \%$ of the set point, the control parameter $\mathrm{Kp}=0.5$ and $\mathrm{Ki}=0.1$ the output voltage at steady state has an average error value of $0 \%$ of the set point.
\end{abstract}

Keywords: photovoltaic, boost converter, proportional integral

\section{Pendahuluan}

Energi fosil adalah energi yang paling banyak digunakan, namun ketersediaannya semakin menipis. Untuk mengantisipasinya, digunakan energi terbarukan. Energi matahari merupakan salah satu sumber energi baru dan terbarukan yang dapat digunakan untuk pembangkit listrik [1]. Pemanfaatan panel surya sebagai pembangkit dapat dihubungkan langsung dengan grid melalui sebuah inverter. Inverter merupakan perangkat yang paling 
umum digunakan sebagai konverter untuk mengubah tegangan DC ke dalam tegangan AC. Permasalahan ketika panel surya dihubungkan langsung dengan grid adalah tegangan yang terhubung pada sistem grid tidak dapat dikontrol [2]. Karakteristik tegangan dan arus keluaran panel surya tergantung pada banyak faktor, diantaranya iradiasi matahari yang diterima panel surya dan besar beban yang disuplai panel surya [3]. Salah satu metode yang diterapkan untuk menjaga tegangan keluaran inverter tetap kostan adalah menjaga nilai tegangan inverter pada besaran tertentu. Hal ini dapat di lakukan dengan merancang sebuah converter menggunakan umpan balik tegangan (voltage feedback). Sistem umpan balik tegangan akan menjaga tegangan keluaran converter konstan dengan mengumpan balikkan tegangan ke sistem kontrol pemicuan PWM (Pulse Width Modulation) sehingga dapat mengatur pulsa pemicuan PWM ke MOSFET. Nilai tegangan grid yang lebih besar dibanding tegangan keluaran panel surya menyebabkan perlunya converter yang dapat menaikan tegangan ( boost converter). Pada penelitian [4], [5] dibahas sistem umpan balik tegangan, namun tidak menggunakan converter penaik tegangan dan belum diaplikasikan pada inverter . Pada penelitian [6] dibahas mengenai converter penaik tegangan dengan umpan balik tegangan mengunakan rangkaian pemicu TL494 sehingga hasil pengontrolanya memiliki nilai error yang relatif besar.

Pada Penelitian ini dirancang boost converter menggunakan umpan balik tegangan sebagai suplai inverter menggunakan rangkaian pemicu dsPIC30F4011 dengan metode kontrol proportional integral, dilakukan dengan tahapan perhitungan komponen, verifikasi menggunakan software PSIM 9.0 dan diimplementasikan melalui hardware.

Tujuan penelitian ini adalah merancang boost converter, mengetahui kinerja boost converter dengan umpan balik tegangan dengan variasi tegangan masukan, dan mengetahui parameter kontrol yang sesuai dengan boost converter yang dirancang.

\section{Metode}

Perancangan boost converter dengan kontrol proportional integral yang dilakukan terdiri dari beberapa blok utama, yaitu blok suplai AC 1 fasa, blok rangkaian daya, blok rangkaian kontrol, dan blok sensor tegangan. Blok rangkaian daya terdiri dari full-wave bridge rectifier dan boost converter. Blok rangkaian kontrol terdiri dari mikrokontroler 16-bit dsPIC30F4011 dan MOSFET driver. Diagram blok perangkat keras yang dirancang ditunjukkan pada Gambar 1.

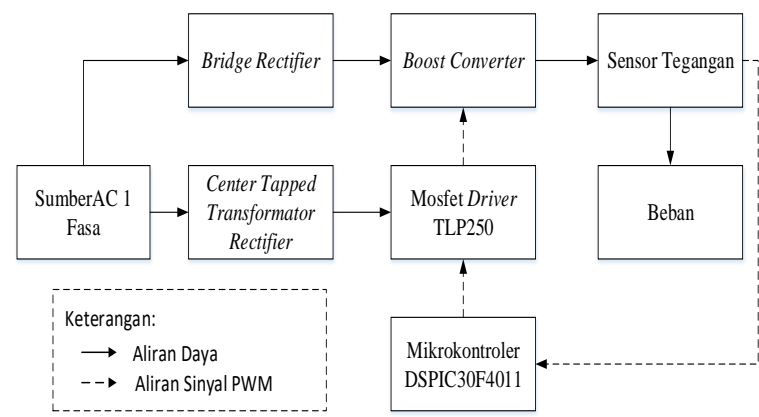

Gambar 1. Blok Diagram Alat

\subsection{Rangkaian Daya Boost Converter}

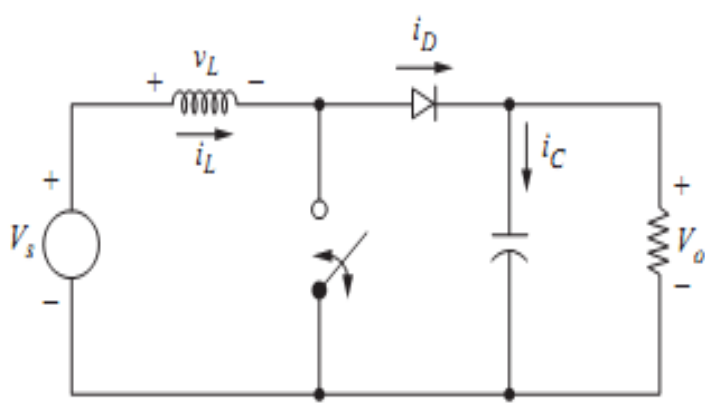

\section{Gambar 2. Rangkaian Boost Converter}

Boost converter bekerja pada dua mode. Mode pertama adalah saat MOSFET on, tegangan induktor sama dengan tegangan masukan. Dioda dalam kondisi pra-tegangan mundur. Induktor akan mulai menyimpan energi dalam bentuk energi magnetik. Energi yang tersimpan pada kapasitor digunakan untuk mensuplai beban.

$V_{L}=\operatorname{Vin}=L \frac{d I_{L}}{d t}$

$\frac{\Delta I_{L}}{\Delta t}=\frac{\Delta I_{L}}{D T}=\frac{V i n}{L}$

$\Delta I_{L, O N}=\frac{V i n D T}{L}$

Mode kedua adalah saat MOSFET off. Dioda pada kondisi pra-tegangan maju. Energi yang tersimpan pada induktor akan dialirkan melalui dioda untuk mengisi kapasitor dan mensuplai beban.

$V_{L}=V_{\text {in }}-V_{o}$

$V_{L}=L \frac{d I_{L}}{d t}$

$\left(\frac{d I_{L}}{d t}\right)=\frac{V i n-V o}{L}$

$\Delta I_{L, O F F}=\frac{(V i n-V o)(1-D) T}{L}$ 
Karena arus induktor konstan, maka dari persamaan (1) dan (2) didapatkan:

$$
\begin{aligned}
& \Delta I_{L, O F F}+\Delta I_{L, O N}=0 \\
& \frac{V i n D T}{L}+\frac{(V i n-V o)(1-D) T}{L}=0 \\
& V_{\text {in }} \times D=\left(V_{o}-V_{i n}\right) \times(1-D) \\
& \frac{V_{O}}{V_{\text {in }}}=\frac{1}{(1-D)}
\end{aligned}
$$

Tabel 1. Spesifikasi Boost Converter

\begin{tabular}{cc}
\hline Parameter & Nilai \\
\hline Frekuensi pemicuan & $20 \mathrm{kHz}$ \\
Duty cycle $(D)$ & $10 \%-80 \%$ \\
MOSFET & IRFP460 \\
Dioda & MUR1560 \\
Induktor & $3100 \mu \mathrm{H}$ \\
Kapasitor & $470 \mu \mathrm{F} / 450 \mathrm{~V}$ \\
\hline
\end{tabular}

Komponen penyusun boost converter ini antara lain:

\section{Saklar}

Komponen pensaklaran yang digunakan adalah MOSFET. Pemilihan MOSFET mempertimbangkan nilai tegangan dan arus konverter. MOSFET yang dipakai adalah IRFP460 yang mempunyai tegangan drain source $\left(V_{D S}\right)$ 500 volt dan arus drain ( $\left.\mathrm{I}_{\mathrm{D}}\right)$ maksimal 20 ampere [7]. MOSFET IRFP460 aman untuk digunakan karena tegangan keluaran yang diinginkan sebesar $350 \mathrm{~V}_{\mathrm{DC}}$ dan arus maksimal sebesar $0.71 \mathrm{~A}$.

\section{Dioda}

Dioda yang digunakan adalah MUR1560, dimana dioda tipe ini mempunyai waktu pemulihan sangat cepat yaitu kurang dari 55ns. Dioda MUR1560 memiliki kemampuan tegangan maksimal 600 volt dan arus hingga 15 ampere, sehingga aman digunakan pada boost converter yang dirancang karena tegangan keluaran yang diinginkan sebesar $350 \mathrm{~V}_{\mathrm{DC}}$ dan arus maksimal sebesar $0.71 \mathrm{~A}$.

\section{Induktor}

Induktor yang digunakan merupakan induktor solenoida yang dibuat dari kawat tembaga yang dililitkan pada inti ferit. Perhitungan induktansi dapat diperoleh dengan persamaan [8]:

$$
\begin{aligned}
& L_{\text {min }}=\frac{D \min (1-D \min )^{2} R \max }{2 f \min } \\
& L_{\text {min }}=\frac{0,1(1-0,1)^{2} 500}{2 \times 20.000} \\
& L_{\text {min }}=1010 \mu \mathrm{H}
\end{aligned}
$$

Agar boost converter bekerja pada mode operasi Continous Condutcion Mode (CCM), maka induktansi yang dibuat harus lebih besar dari induktansi minimal, sehingga induktansi yang digunakan sebesar $3100 \mu \mathrm{H}$.

\section{Kapasitor}

Kapasitor berfungsi sebagai filter untuk membatasi ripple tegangan keluaran konverter. Kapasitor yang digunakan untuk perancangan boost converter ini memiliki ripple 1\%. Besar kapasitor dapat dihitung dengan persamaan 5 berikut [8]:

$$
\begin{aligned}
C_{\text {min }} & =\frac{D_{\max }}{\% V_{r} \cdot R \min , f_{\min }} \\
\mathrm{C}_{\min } & =\frac{0,8}{0,01.500 .20 .000} \\
\mathrm{C}_{\text {min }} & =8 \mu \mathrm{F}
\end{aligned}
$$

Pada realisasinya, kapasitor yang dipasang adalah $470 \mu \mathrm{F} /$ 450 V. Nilai kapasitansi sebesar $8 \mu \mathrm{F}$ tidak dapat ditemukan di pasaran, sehingga dipilih nilai kapasitansi kapasitor di atas nilai perhitungan. Pemilihan nilai kapasitansi kapasitor yang lebih besar daripada nilai perhitungan bertujuan untuk mengurangi ripple tegangan keluaran.

\section{Sensor Tegangan}

Pada perancangan umpan balik tegangan terdapat resistor pembagi tegangan pada keluaran konverter. Nilai resistor ditentukan dengan menggunakan persamaan :

$$
\begin{aligned}
& V_{\text {OUT }}=V_{R E F}\left(1+\frac{R_{1}}{R_{2}}\right) \\
& 400=5\left(1+\frac{R_{1}}{R_{2}}\right) \\
& R_{1}=79 R_{2}
\end{aligned}
$$

Nilai tegangan keluaran $V_{\text {OUT }}$ sebesar 400 volt. Nilai tegangan referensi $V_{R E F}$ sebagai acuan pembanding dengan tegangan sebesar 5 volt. Perhitungan persamaan 6 didapat nilai $\mathrm{R}_{1}=79 \mathrm{R}_{2}$, sehingga untuk pemilihan resistor $R_{2}=10 \mathrm{k} \Omega$ maka nilai resistor $R_{1}=790 \mathrm{k} \Omega$.

\section{MOSFET Driver}

Rangkaian TLP250 digunakan untuk mengisolasi dan menguatkan sinyal kontrol proportional integral dengan level tegangan 5 Volt yang dibangkitkan oleh mikrokontroller dsPIC30F4011 menjadi level tegangan yang lebih tinggi untuk memicu MOSFET (Metal Oxide Semiconductor Field Effect Transistor) sebagai driver. TLP250 dipilih sebagai MOSFET driver dengan pertimbangan mudah di dapatkan di pasaran dan dapat drive teganggan dalam rentang $15-30 \mathrm{~V}$ hal ini sesuai dengan kebutuhan MOSFET IRFP460.

\subsection{Perancangan Kontrol Tegangan Proportional- Integral}

Dengan mempertimbangkan segala aspek dan pengaruh dari implementasi parameter PID terhadap kinerja proses sistem inverter satu fasa maka dipilih untuk merancang sistem inverter satu fasa yang menggunakan sistem kendali Proporsional-Integral. Hal ini didasari karena pada pengaplikasian di lapangan, Kontrol Proporsional- 
Integral biasa digunakan untuk pengontrolan proses yang memiliki dinamika relatif cepat (seperti aliran, tekanan, dan level). Berdasarkan sebuah survey dinyatakan bahwa hampir $80 \%$ kontroler PID yang terpasang di industri menggunakan kontrol PI dalam operasinya [9]. Sinyal kontrol proportional-integral digunakan untuk mengumpan balikkan nilai keluaran tegangan dari boost converter dengan mengontrol variabel sinyal dengan suatu nominal konstanta tertentu (Kp dan Ki). Gambar 3 menunjukkan diagram blok dari kontroler proportionalintegral dari sistem.

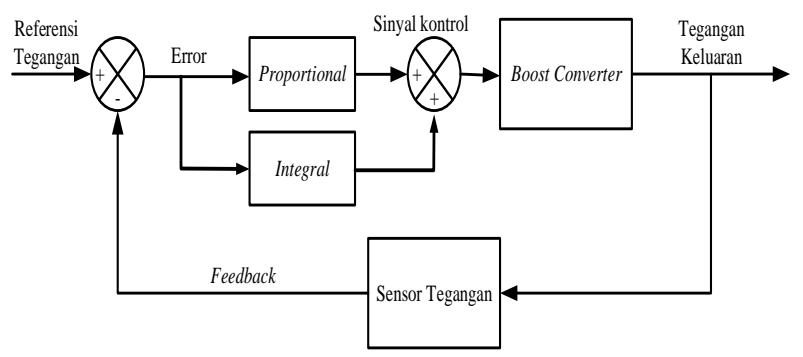

Gambar 3. Perancangan Kontrol Proportional-Integral

Nilai error diperoleh dari hasil pengurangan tegangan aktual yang diukur oleh sensor tegangan dengan nilai referensi tegangan yang diberikan. Setelah nilai error didapatkan, kontroler proportional-integral akan mengalikan nilai error dengan konstanta $\mathrm{Kp}$ dan Ki untuk mendapat nilai penguatan yang berguna untuk proses updating nilai Register PDC (PWM Duty Cycle Comparison Unit). Perubahan nilai register PDC akan mempengaruhin proses pembangkitan sinyal PWM melalui modul MCPWM (Motor Control Pulse Width Modulation Module) yang merupakan sebuah sistem yang dimiliki oleh mikrokontroler dsPIC30F4011 dalam menyederhanankan segala kinerja proses pembangkitan gelombang sinyal PWM.

Berikut adalah persamaan kontroler proportional-integral dalam bentuk transformasi Laplace:

$U(s)=\left[K p+\frac{k i}{s}\right] e(s)$

\section{Hasil dan Analisa}

\subsection{Pengujian Suplai Daya Arus Searah}

Pengujian ini dilakukan untuk mengetahui besar tegangan keluaran hasil dari penyearah dengan transformator CT sebagai suplai tegangan DC untuk rangkaian MOSFET driver TLP250.

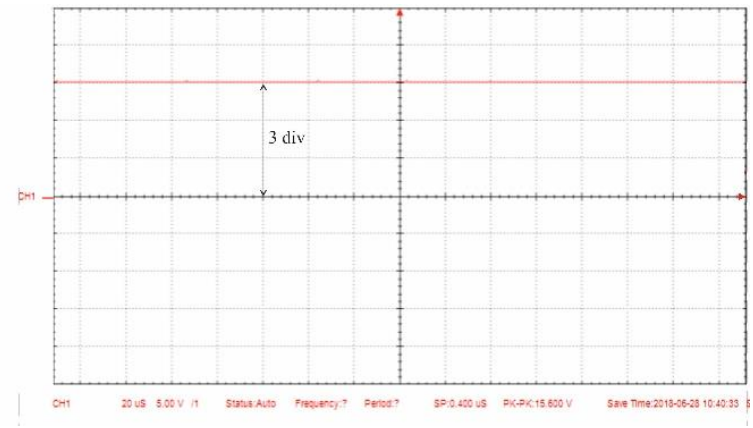

Gambar 4. Gelombang Suplai Daya Arus Searah

Dari pengujian gelombang pada gambar 5, didapatkan tegangan:

$V d c=\operatorname{div} \times \frac{V}{\operatorname{div}}$

$V d c=3 \operatorname{div} \times \frac{5 \mathrm{~V}}{\operatorname{div}}$

$V d c=15 V$

\subsection{Pengujian Keluaran Mikrokontroler dsPIC30F4011}

Pengujian dilakukan dengan membangkitkan sinyal PWM open loop dengan frekuensi sinyal carrier $20 \mathrm{kHz}$. Pengujian tegangan keluaran PWM dapat dilihat pada Gambar 5.

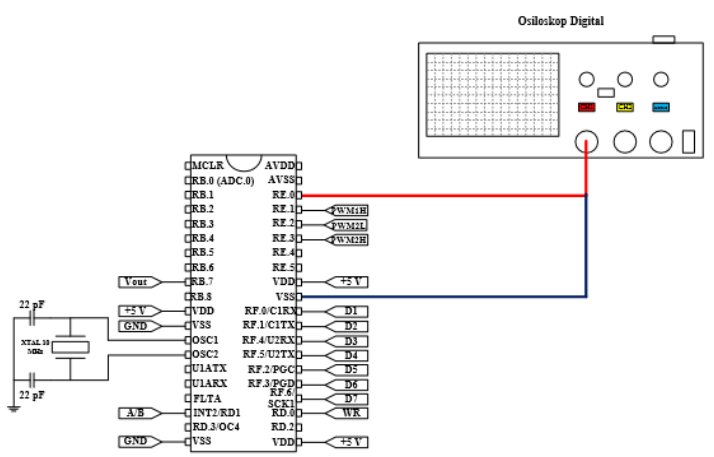

Gambar 5. Rangkaian Pengujian Keluaran Mikrokontroler dsPIC30F4011

Hasil gelombang keluaran sinyal PWM dsPIC30F4011 pada pin RE0 ditunjukkan Gambar 6. 


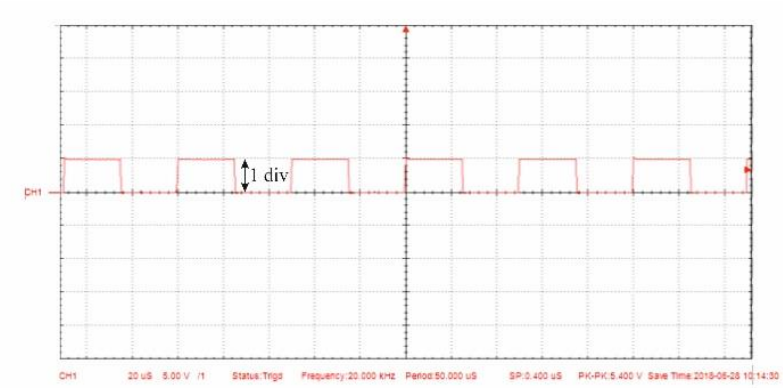

Gambar 6. Keluaran PWM PWM1L (RE0) Dengan Duty Cycle 50\%.

Nilai keluaran sinyal PWM open loop yang dihasilkan memiliki jumlah div $=1$ dengan $\mathrm{V} / \mathrm{div}=5 \mathrm{~V}$, sehingga magnitude sinyal yang dihasilkan adalah sebagai berikut.

$V_{P W M}=1 \times 5 \mathrm{~V} /$ div $\times 1$

$V_{P W M}=5 \mathrm{~V}$

\subsection{Pengujian MOSFET Driver TLP250}

Rangkaian pengujian MOSFET Driver TLP250 ditunjukkan pada Gambar 7.

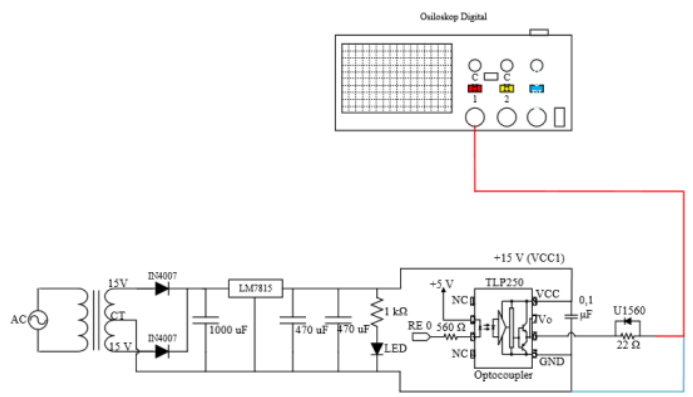

Gambar 7. Rangkaian Pengujian MOSFET Driver TLP250.

Hasil gelombang keluaran MOSFET driver ditunjukkan Gambar 8.

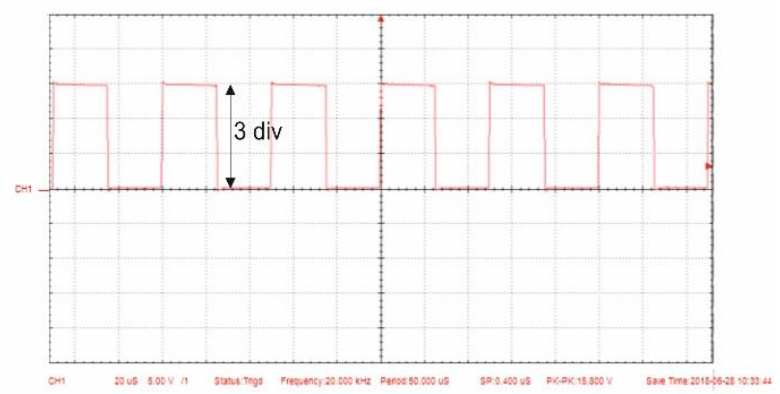

Gambar 8 menunjukkan keluaran MOSFET driver TLP250 membentuk pola yang sama dengan pola sinyal pemicuan PWM yang dibangkitkan oleh mikrokontroler, namun dengan nilai magnitude tegangan yang lebih besar. Keluaran driver TLP250 memiliki nilai 3 div dalam skala $\mathrm{V} /$ div $=5 \mathrm{~V} /$ div, sehingga diperoleh tegangan keluaran MOSFET driver adalah sebagai berikut.

$\mathrm{V}_{\text {MOSFET driver }}=3 \times 5 \mathrm{~V} / \operatorname{div} \times 1$

$\mathrm{V}_{\text {MOSFET driver }}=15 \mathrm{~V}$

Tegangan 15 volt dapat digunakan untuk megaktifkan MOSFET IRFP460 sesuai dengan boost converter yang dirancang.

\subsection{Pengujian Rangkaian Boost Converter Variasi Duty Cycle}

Pengujian rangkaian boost converter variasi duty cycle ditunjukan pada Gambar 9.

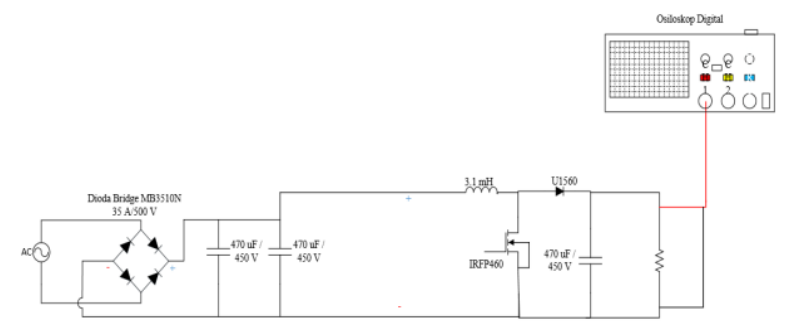

Gambar 9. Rangkaian Pengujian Boost Converter Variasi Duty Cycle

Pengujian boost converter dilakukan dengan cara melihat tegangan masukan dan keluaran saat dilakukan perubahan duty cycle dibangkitkan oleh sinyal PWM. Sumber tegangan yang digunakan adalah tegangan hasil penyearahan dioda bridge sebesar $40 \mathrm{~V}$. Variasi duty cycle yang digunakan dalam pengujian boost converter adalah $10 \%, 20 \%, 30 \%, 40 \%, 50 \%, 60 \%$, dan $70 \%$.

Tabel 2. Hasil Pengujian Boost Converter Variasi Duty Cycle

\begin{tabular}{ccc}
\hline \multirow{2}{*}{ Duty Cycle (\%) } & \multicolumn{2}{c}{ Vout (V) } \\
& Simulasi & Pengukuran \\
\hline 10 & 44 & 42 \\
20 & 49,9 & 48 \\
30 & 57 & 56 \\
40 & 66,6 & 64 \\
50 & 79,9 & 80 \\
60 & 99,9 & 95 \\
70 & 133 & 125 \\
\hline
\end{tabular}

Gambar 8. Gelombang Keluaran MOSFET Driver TLP250 Dengan Duty Cycle 50\%. 


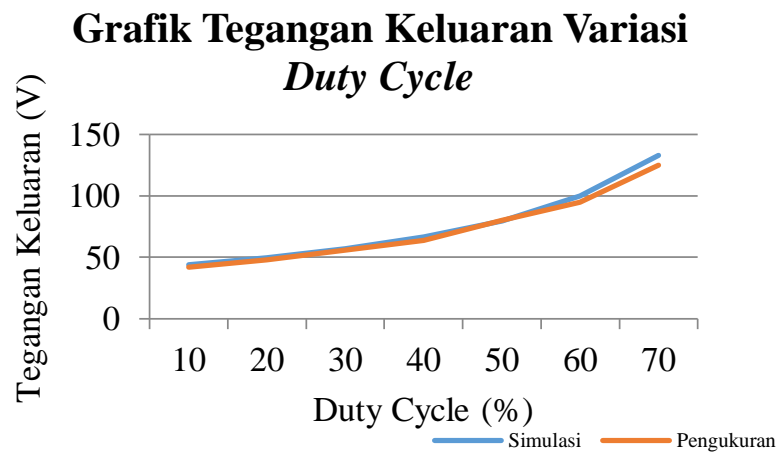

Gambar 10. Grafik Tegangan Keluaran Variasi Duty Cycle

Pada Tabel 2 dan Gambar 10 terlihat bahwa semakin besar duty cycle, maka semakin besar tegangan keluaran. Hasil simulasi tidak jauh berbeda dengan hasil pengukuran pada perangkat keras boost converter. Perbedaan terjadi karena dalam simulasi tidak mempertimbangkan rugi-rugi tiap komponen penyusun boost converter.

\subsection{Pengujian Boost Converter dengan Umpan Balik Tegangan}

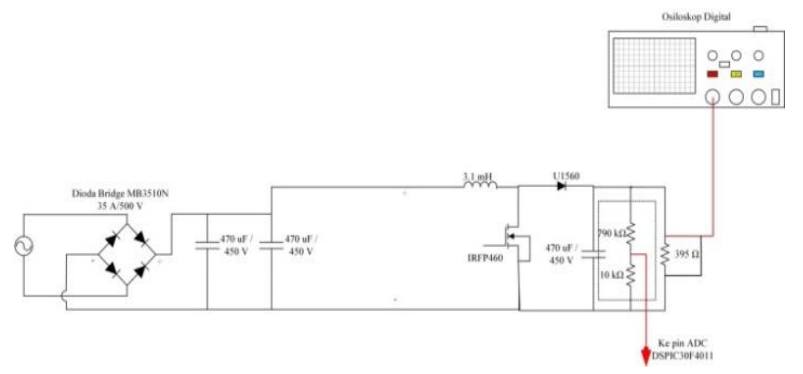

Gambar 11 Rangkaian Pengujian Boost Converter Umpan Balik Tegangan

Gambar 11 merupakan rangkaian pengujian tegangan keluaran boost converter dengan umpan balik tegangan. Pengujian menggunakan tegangan masukan awal sebesar 25 volt, duty cycle $50 \%$, dan set point tegangan ditetapkan pada nilai 50 volt dengan menggunakan beban resistif $395 \Omega$.Pengujian dilakukan dengan memvariasikan tegangan masukan boost converter dengan nilai 15 volt, 20 volt, 30 volt, dan 35 volt dan mengubah parameter kontrol yang digunakan .

\subsubsection{Pengujian dengan Nilai $K p=0.5$ dan $K i=0.0$}

Hasil pengujian umpan balik tegangan dengan nilai $\mathrm{Kp}=0.5$ dan $\mathrm{Ki}=0.0$ dapat dilihat pada Tabel 3 .
Tabel 3. Hasil Pengujian Umpan Balik Tegangan Dengan Nilai Kp=0.5 Dan Ki =0.0

\begin{tabular}{cccc}
\hline Set Point (V) & Vin (V) & Vout (V) & Error (\%) \\
\hline 50 & 15 & 30 & 40 \\
50 & 20 & 40 & 20 \\
50 & 30 & 60 & 20 \\
50 & 35 & 70 & 40 \\
\hline
\end{tabular}

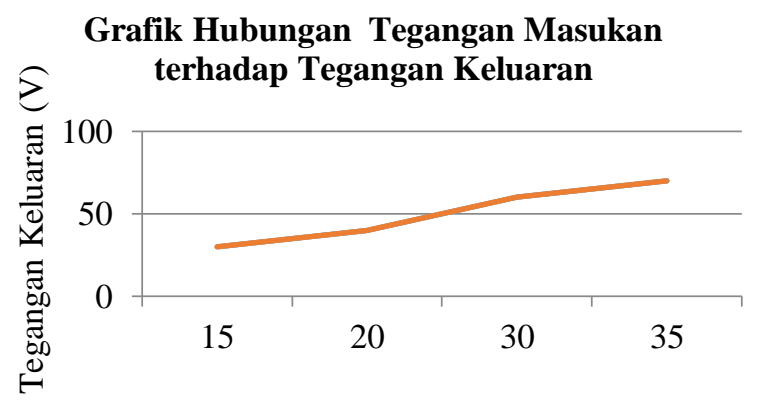

Tegangan Masukan (V)

Gambar 12. Grafik Hubungan Tegangan Masukan Dengan Tegangan Keluaran Pada Keadaan Steady State

Dari Tabel 3 dan Gambar 12 terlihat bahwa Semakin besar perubahan tegangan masukan maka error tegangan keluaran akan semakin besar. Dapat dilihat bahwa tegangan keluaran tidak dapat dijaga konstan pada 50 volt dengan error rata-rata sebesar $30 \%$ dari set point.

\subsubsection{Pengujian dengan Nilai $K p=0.0$ dan $K i=0.1$}

Hasil pengujian umpan balik tegangan dengan nilai $\mathrm{Kp}=0.0$ dan $\mathrm{Ki}=0.1$ dapat dilihat pada Tabel 4 .

Tabel 4. Hasil Pengujian Umpan Balik Tegangan Dengan Nilai $K p=0.0$ Dan $K i=0.1$

\begin{tabular}{cccc}
\hline Set Point (V) & $\begin{array}{l}\text { Vin } \\
\text { (V) }\end{array}$ & Vout (V) & Error (\%) \\
\hline 50 & 15 & 50 & 0 \\
50 & 20 & 50 & 0 \\
50 & 30 & 50 & 0 \\
50 & 35 & 50 & 0 \\
\hline
\end{tabular}

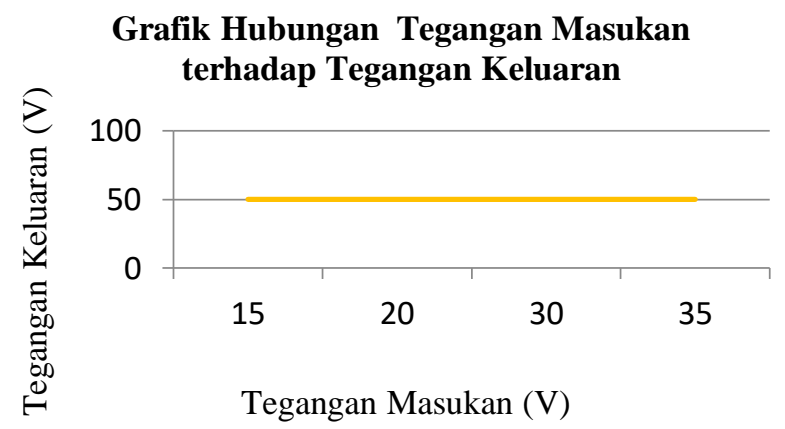

Gambar 13. Grafik Hubungan Tegangan Masukan Dengan Tegangan Keluaran Pada Keadaan Steady State 
Dari Tabel 4 dan Gambar 13 terlihat bahwa tegangan keluaran sama dengan set point. Hasil ini menunjukan bahwa parameter yang digunakan sesuai dengan sistem kontrol yang telah di rancang, akan tetapi pengamatan secara langsung pada pengukuran menunjukan bahwa terdapat error dengan nilai yang kecil hal ini dapat ditunjukan pada Gambar 14.

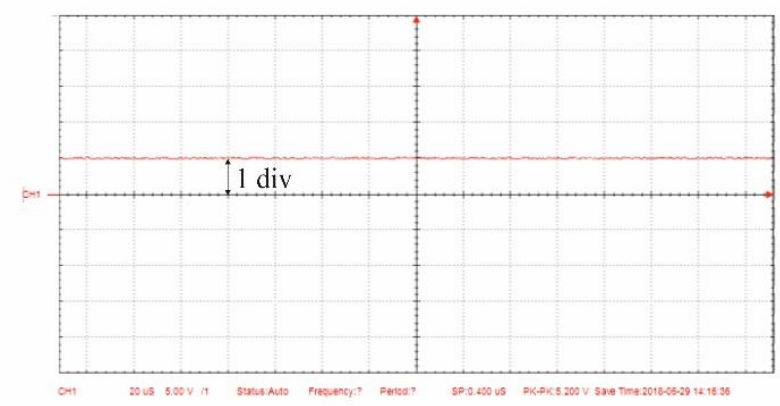

Gambar 14. Gelombang Keluaran Variasi Tegangan Inputan $15 \mathrm{~V}$

\subsubsection{Pengujian dengan Nilai $K p=0.5$ dan $K i=0.1$}

Hasil pengujian umpan balik tegangan dengan nilai $\mathrm{Kp}=0.5$ dan $\mathrm{Ki}=0.1$ dapat dilihat pada Tabel 5.

Tabel 5. Hasil pengujian umpan balik tegangan dengan nilai $\mathrm{Kp}=0.5$ dan $\mathrm{Ki}=0.1$

\begin{tabular}{cccc}
\hline $\begin{array}{c}\text { Set Point } \\
(\mathbf{V})\end{array}$ & $\begin{array}{c}\text { Vin } \\
(\mathbf{V})\end{array}$ & Vout $(\mathbf{V})$ & Error $(\%)$ \\
\hline 50 & 15 & 50 & 0 \\
50 & 20 & 50 & 0 \\
50 & 30 & 50 & 0 \\
50 & 35 & 50 & 0 \\
\hline
\end{tabular}

Grafik Hubungan Tegangan Masukan terhadap Tegangan Keluaran

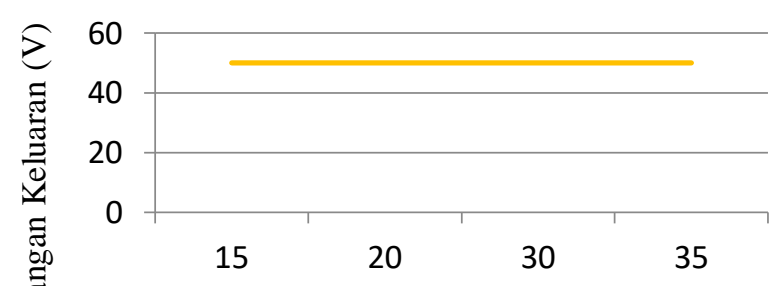

Tegangan Masukan (V)

Gambar 15. Grafik Hubungan Tegangan Masukan Dengan Tegangan Keluaran Pada Keadaan Steady State

Dari Tabel 5 dan Gambar 15 terlihat bahwa tegangan keluaran sama dengan set point. Hasil ini menunjukan bahwa parameter yang digunakan sesuai dengan sistem kontrol yang telah di rancang. Hasil pengamatan secara langsung pada pengukuran menunjukan bahwa gelombang keluaran pada keadaan steady state memiliki nilai error lebih kecil dibandingkan parameter kontrol lainya. Hal ini dapat dilihat pada Gambar 16.

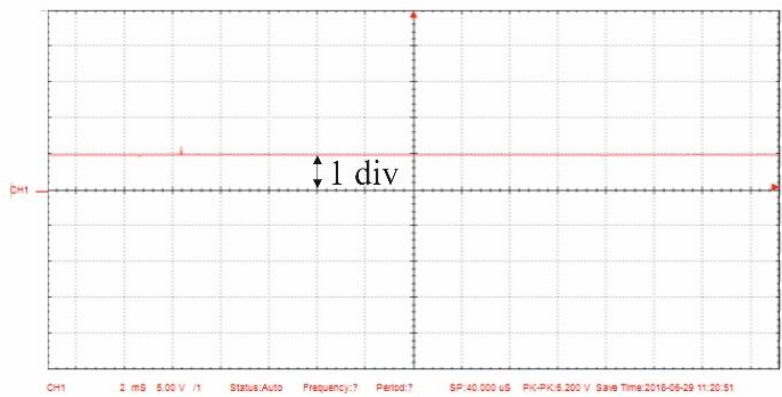

Gambar 16. Gelombang Keluaran Variasi Tegangan Inputan 15 V

\section{Kesimpulan}

Boost converter berhasil dibuat dan dapat digunakan untuk menaikan tegangan keluaran dengan menjaga tegangan keluaran tetap konstan pada level tegangan masukan yang berbeda. Pada percobaan variasi duty cycle, semakin besar duty cycle, semakin besar tegangan keluaran boost converter.. Pada pengujian umpan balik tegangan dengan nilai $\mathrm{Kp}=0.5$ dan $\mathrm{Ki}=0.0$ tegangan keluaran memiliki nilai error rata-rata sebesar $30 \%$ dari set point. Pada pengujian umpan balik tegangan dengan nilai $\mathrm{Kp}=0.0$ dan $\mathrm{Ki}=0.1$ tegangan keluaran memiliki nilai error rata-rata sebesar $0 \%$ dari set point. Pada pengujian umpan balik tegangan dengan nilai $\mathrm{Kp}=0.5$ dan $\mathrm{Ki}=0.1$ tegangan keluaran memiliki nilai error rata-rata sebesar 0\% dari set point. Penelitian ini dapat dikembangkan dengan perancangan suplai daya menggunakan energi terbarukan lain, menggunakan topologi konverter lain, menggunakan metode kontrol lain, dan umpan balik arus.

\section{Referensi}

[1]. L. Antonio dan H. Steven, Handbook of Photovoltaic Science and Engineering, West Sussex: John Wiley \& Sons, 2003.

[2]. S. Muhammad, "Pemanfaatan Solar Cell Sebagai Pembangkit Listrik Terbarukan," Jurnal Teknik, vol. 27, no. 3, Okt. 2014

[3]. R. W. Stuart dkk., Applied Photovoltaics, Cornwall: Earthscan, 2007.

[4]. A. J. Marco, "Perancangan DC Chopper Tipe BuckBoost Converter Penguatan Umpan Balik IC TL 494," Laporan Tugas Akhir, Departemen Teknik Elektro, Universitas Diponegoro, Semarang, 2015.

[5]. W. C. Lukman, "Kinerja Konverter Arus Searah tipe Buck Converter dengan Umpan Balik Tegangan berbasis TL494," Laporan Tugas Akhir, Departemen Teknik Elektro, Universitas Diponegoro, Semarang, 2017. 
[6]. A. A. Muhammad, " Perancangan Boost Converter Menggunakan Voltage Feedback Pada Panel Surya," Laporan Tugas Akhir, Departemen Teknik Elektro, Universitas Diponegoro, 2017.

[7]. VISHAY, "Power MOSFET IRFP460, SiHFP460," p. 9, 2011.
[8]. W. H. Daniel "Introduction to Power Electronics," Indiana: Printice-Hall International, 1997

[9]. I. Setiawan, Kontrol PID untuk Proses Industri. Jakarta, Indonesia: PT. Elex Media Komputindo, 2008. 